\title{
Evaluation of the vulnerability of families assisted in Primary Care in Brazil
}

\author{
Tharsila Martins Rios da Silva ${ }^{1}$ \\ Márcia Regina Martins Alvarenga ${ }^{2}$ \\ Maria Amélia de Campos Oliveira ${ }^{3}$
}

Objective: to characterize the profiles of families in the area covered by a Primary Health Center and to identify those in a vulnerable situation. Method: this is an epidemiological, observational, cross-sectional and quantitative study. 320 home visits were made, defined by a random sample of the areas covered by the Urban Center 1 in the city of São Sebastião, in Brazil's Federal District. A structured questionnaire was used for data collection, elaborated based on the Family Development Index (FDI). Results: there was a predominance of young families, women, and low levels of schooling. The FDI permitted the identification of families in situations of "high" and "very high" vulnerability. The most critical dimensions were: "access to knowledge" and "access to work". Conclusion: the study indicated the importance of greater investments in the areas of education, work and income, and highlighted the need for the use of a wider concept of vulnerability by the health services.

Descriptors: Family; Health Evaluation; Vulnerability; Primary Health Care; Needs Assessment; Comprehensive Health Care.

${ }^{1}$ RN, MSc, Secretaria de Estado de Saúde do Distrito Federal, Brazil.

2 PhD, Professor, Escola de Enfermagem, Universidade Estadual de Mato Grosso do Sul, Brazil.

${ }^{3}$ PhD, Full Professor, Escola de Enfermagem, Universidade de São Paulo, Brazil. 


\section{Avaliação da vulnerabilidade de famílias assistidas na Atenção Básica}

Objetivo: caracterizar o perfil de famílias da área de abrangência de uma Unidade Básica de Saúde e identificar aquelas em situação de vulnerabilidade. Método: tratase de um estudo epidemiológico observacional, transversal e quantitativo. Foram realizadas 320 visitas domiciliárias, definidas por uma amostra aleatória das áreas de abrangência do Posto Urbano-1, em São Sebastião, DF. Para coleta de dados, utilizouse um questionário estruturado, elaborado a partir do Índice de Desenvolvimento da Família (IDF). Resultados: os resultados revelaram famílias jovens, com predomínio do sexo feminino e escolaridade baixa. O IDF permitiu identificar famílias em situação de vulnerabilidade grave e muito grave. As dimensões mais críticas foram: "acesso ao conhecimento" e "acesso ao trabalho". Conclusão: por meio deste o estudo sinalizouse a importância de maiores investimentos na área da educação, trabalho e renda, e destacou-se a necessidade da utilização do conceito ampliado de vulnerabilidade pelos serviços de saúde.

Descritores: Família; Avaliação em Saúde; Vulnerabilidade; Atenção Primária à Saúde; Determinação de Necessidades de Cuidados de Saúde; Assistência Integral à Saúde.

\section{Evaluación de la vulnerabilidad de familias asistidas en la Atención Básica}

Objetivo: caracterizar el perfil de familias del área de abarcamiento de una Unidad Básica de Salud e identificar aquéllas en situación de vulnerabilidad. Método: Se trata de un estudio epidemiológico observacional, transversal y cuantitativo. Fueron realizadas 320 visitas domiciliarias definidas por una muestra aleatoria de las áreas de abarcamiento del Puesto Urbano-1 en São Sebastião, DF. Para recogida de datos, se utilizó un cuestionario estructurado, elaborado desde el Índice de Desarrollo de la Familia (IDF). Resultados: revelaron familias jóvenes, con predominio del sexo femenino y escolaridad baja. El IDF permitió identificar familias en situación de vulnerabilidad grave y muy grave. Las dimensiones más críticas fueron: "acceso al conocimiento" y "acceso al trabajo". Conclusión: el estudio señalizó la importancia de mayores inversiones en el área de la educación, trabajo y renta, y destacó la necesidad de la utilización del concepto ampliado de vulnerabilidad por los servicios de salud.

Descriptores: Familia; Evaluación en Salud; Vulnerabilidad; Atención Primaria de Salud; Evaluación de Necesidades; Atención Integral de Salud.

\section{Introduction}

Health surveillance is one of the important tasks carried out by Primary Health Care services. It requires the monitoring of the living and health conditions of families in a specified area, particularly those in a vulnerable situation. Its aim is the identification of the families' health needs, with a view to intervention(1-2).

Surveillance actions, however, are often neglected by Family Health Strategy (FHS) teams, either because such teams cannot rely on having the necessary tools or resources for identifying families in situations of greater vulnerability, or because they do not understand the wider concept of vulnerability, which relates to the complex of aspects which go beyond the individual plane, as they relate to collective and contextual ones, which result in susceptibility to the process of illness and which demand actions which are social responses ${ }^{(3)}$. The theoretical and methodological advances in the area of health, in particular in collective health, are not always 
immediately incorporated into health practices, which often results in gaps, demanding transformations and innovations in the area of health(4).

The relevance of studies relating to vulnerability, principally in the field of nursing, lies in the fact that the incorporation of the concept allows better comprehension of the determinants of the health- illness process ${ }^{(5)}$.

Equally, it is necessary to widen the concept of vulnerability to include social questions and the essence of its production; without, however, restricting one's approach to individual aspects, as grasping the concept of vulnerability is related to the integrality in the health services' actions and to the broadening of the understanding of the phenomena of health and illness ${ }^{(5)}$.

If, on the one hand, the widened conception of vulnerability as a complex phenomenon characterized by socially-determined psychological, cultural, economic and political questions contributes to a better understanding of the health-illness process, on the other it demands the use of a labor process and activities which guide the care for the needs of collective health and health work ${ }^{(4)}$.

This study is intended to contribute to the identification of the most vulnerable families in the context of the Family Health Strategy. Its objectives are to characterize the profile of families in the coverage area of a particular Family Health Center, and to identify those in situations of vulnerability.

Its justification results from the need to contribute to the reorientation of health actions, which are still strongly marked by a focus on the individual, by means of work strategies and resources capable of identifying and intervening in situations of vulnerability which affect the families, as well as supporting critical reflection on the part of health care professionals.

\section{The concept of vulnerability}

The term 'vulnerability' arose in the field of Human Rights, where it designated "groups or individuals that are juridical or politically frail in promoting, protecting or assuring their citizenship rights" (6). It has been widely discussed by researchers and health care professionals since the aids epidemic. At the time, epidemiological studies related the chances of some people or of a specific populational group (the 'exposed') transferring to belong to the harmed group (the 'affected'), based on a probabilistic and mathematical relationship in which a specified phenomenon, associated with other variables, determined the association or non-association between pathological events(7).
Innumerable criticisms were made by different social movements concerning this process of causal inference related to the epidemiology of risk, as it rouses prejudice and discrimination against specific groups in society, related mainly to sexual orientation, as well as blaming individuals for their illnesses ${ }^{(7)}$. It was, therefore, necessary to re-think the relationship between risk and aids, and to advance in the discussions about vulnerability which began to be used to widen understanding about the syndrome ${ }^{(5)}$. Viewed from the perspective of vulnerability, interpretation of the epidemic changed, and it began to be interpreted as the result of the interactions of the individual, programmatic and social dimensions.

The concept of vulnerability is related to the complex of individual, collective and social aspects, as well as those related to availability of resources, which can result in susceptibility to illness, or to health hazards ${ }^{(3)}$. These, in their turn, are not related to purely individual aspects, but also to collective and contextual aspects which involve social, political, cultural and economic questions ${ }^{(3-7)}$.

As it involves both individual and collective aspects, vulnerability demands the integration of three lines of action, which relate to the relationships between the social and programmatic situations, and how these affect individuals' living and health conditions. These lines of action may be defined as individual, social and programmatic vulnerability ${ }^{(7)}$

Individual vulnerability is understood as the extension and the quality of the information which is available to people: the capacity these have to elaborate the information and incorporate it into daily life, and the interest they have in applying it in practice. Social vulnerability is related to the obtaining of information, to the content and meaning of the information, and to the capacity to put it into practice. It is related to material, cultural, political and moral aspects which have to do with life in society. Programmatic vulnerability is understood as the analysis of programs' and institutions' ability to respond to socially given conditions of vulnerability ${ }^{(7)}$.

The concept of vulnerability used in this study is one that interlinks the individual, social and programmatic aspects, considering health practices as socially and historically determined, with the social determination of health-illness process as the guiding principle.

Thus, considering that vulnerability is understood in the individual, social and programmatic planes, it involves the need to mobilize other structures which are not restricted to the singular dimension of the health 
services, that is, it demands intersectorial actions. Some authors emphasize the importance of mobilizing the sectors of education, work, and social, legal and cultural well-being as responses which aim to reduce vulnerability ${ }^{(7)}$.

\section{Material and Method}

This is an observational, cross-sectional and epidemiological study with a quantitative approach. It was undertaken in the coverage area of the FHS unit Urban Center 1, comprised of teams Bosque 1 and Vila Nova 2, in the satellite city of São Sebastião in the Federal District. The Federal District is in the Center-West of Brazil, and its capital is Brasilia, located approximately $26 \mathrm{~km}$ from São Sebastião, where this study was carried out.

The concept of 'family' used by the Brazilian Institute of Geography and Statistics (IBGE) was adopted by the study. This defines the family as "a complex of people linked by bonds of kinship, domestic dependence or societal norms, who reside in the same household and, also, the person who lives alone in a residential unit"(8). It was adopted for this study as it permits the evaluation of situations of vulnerability of families which live in the same residence, which facilitated data collection. This concept is related to that adopted by the FHS, which considers the home as a social and historical space where family relationships are constructed(9).

The study's population was comprised of 1,849 families registered in the areas covered by the two teams in the FHS Urban Center 1, who are responsible for five micro-areas each. This information was taken from the Primary Care Information System (SIAB) from the Primary Care Center in question.

For data collection, a sample of 320 families was defined using the method of simple random sampling, which uses estimations of populational proportions and is used when a register is available, that is, when the population is finite ${ }^{(10)}$. A sampling error of $5 \%$ was taken into account, which allows the defining of confidence intervals of $95 \%{ }^{(10)}$. The use of a sample involves accepting that there is a margin of error, as the sample does not represent the characteristics of the population studied perfectly ${ }^{(10)}$.

For data collection, a random selection was made from the families registered on the Primary Care Information System (SIAB) and which made up the defined sample. The SIAB is present in all the FHS teams in the city of São Sebastião and all the professionals in the team have access to the system to update information, as well as to use for possible interventions in health practices. To facilitate the data collection, the families selected were separated into their respective micro-areas.

The data was collected between October 2010 and February 2011, through interviews undertaken by one of the researchers, in the families' homes, with the collaboration of Community Health Workers ( $\mathrm{CHW}$ ) and nursing assistants from the health center. These professionals, who knew the families registered, accompanied the researcher so as to facilitate her introduction to the families.

The inclusion criteria was for the family to be registered with the FHS teams and for the interviewee to be aged 18 or over at the time of the visit. The exclusion criteria were families who were not at home when the visit was made, and members of families who refused to participate in the interview.

So as to meet the requirements of the National Health Council's Resolution 196* the present study was forwarded to the Federal District Secretariat for Health's Ethics Committee. After its approval by the committee, under Protocol 313/10, each participant gave their free and informed consent to respond to a structured questionnaire that took into consideration the families' different stages of development, as well as conditions which impact on the family health-illness process. This information was important for the relationship with vulnerability, as the presence of children, adolescents and the elderly entails a need for greater attention to the family, as it influences the family's vulnerability. The same happened in relation to the family's living conditions, such as the presence in the home of treated water, garbage collection and electricity.

The interviews, which involved interviewing one member of the family who met the inclusion criteria, took place in the homes of the selected families. The interviews were undertaken by one of the researchers and the information collected was recorded on paper at the time of the interview.

The Family Development Index (FDI) was used to identify families in vulnerable situations ${ }^{(11)}$. The FDI is a synthetic indicator which can be calculated for each family and which can be applied to any demographic group, such as families headed by women, the elderly, or people of African descent.

* Resolution 196 concerns research involving human beings. Translator's note. 
The concept of vulnerability adopted in the present study showed itself to be closer to that proposed in the FDI, as it aims to relate the families' individual aspects with the collective and contextual aspects in which the families were inserted, leaving the individual plane aside.

The instrument was constructed based on information from the basic questionnaire from the National Household Sample Survey (PNAD), whose original composition is comprised of six dimensions, 26 components and 48 indicators. The six dimensions obtained based on the PNAD basic questionnaire, and which are related to the families' living conditions, are: absence of vulnerability (characterized by the additional volume of resources which the family needs to meet its basic needs, such as, for example, resources necessary to meet the needs of pregnant women, children and the elderly); access to knowledge; access to work; availability of resources; child development and housing conditions $^{(11)}$.

In line with the FDI's proposal, this permits the adding or removing of indicators, as well as the attributing of weighting in accordance with social preferences, and should come from social debate(11). Therefore, with a view to expanding the information relating to the families' situations of vulnerability, some adaptations were made to the proposed FDI, based on discussions held by the research group, which resulted in changes in the instrument. Components and indicators were added and removed, but the dimensions were kept. These modifications were implemented for closer approximation to the concept of vulnerability adopted in this study.

The Statistical Package for the Social Sciences SPSS version 17 - was used for analysis of the data. This considered the FDI's indicators and components defined after the modifications, and its dimensions. Each indicator corresponded to a yes/no question from the FDI questionnaire. Each response considered positive for the family received a score of 1 ; responses considered negative for the family received no points.

The synthetic indicator was built from the questions of the Census, organized according to the guiding axes or the entitled subjects, and their components, which, in turn, were organized in dimensions.

Each component's synthetic indicator resulted from the arithmetical average of the variables used to represent the components of each dimension. In the same way, each dimension's synthetic indicator was the arithmetical average of its respective components. Thus, the total FDI was calculated based on the arithmetical average of the synthetic indicators of the dimensions which it was composed of ${ }^{(12)}$.

The cut-off points proposed by the FDI's authors for classifying the families in vulnerability are: 'very high vulnerability' (FDI below 0.50) 'high vulnerability' (FDI between 0.50 and 0.67 ) and 'acceptable situation' (FDI above 0.67$)^{(11)}$.

The relationship between the indicators' arithmetical organization and the classification of the families' vulnerability relates to the concept of vulnerability adopted in this study, as it is a way of operationalizing and summarizing in a number the questions about the context in which the families are inserted.

\section{Results}

The results present the object of the study: the families' profiles.

\section{Sociodemographic profile of the families}

The families interviewed had on average four members, making a total of 1,252 persons. Among the members of the families, it was observed that women predominated $(52.8 \%)$, that the average age was 27 , and that the median age was 25 , varying from 0 to 89 , with standard variation of 18.2 years, which indicates a lack of homogeneity among the members. The mostcommonly declared 'race' in the families was 'mixed' $(60.8 \%)$ and the most common marital situation was single (58.9\%). In addition, it was observed that there was a low level of schooling among members of the families, with the most common response being 'primary education incomplete' (40\%). The majority of family members were from the Center-West region of Brazil (46.7\%).

In order to produce the monthly family income, necessary for the 'in poverty' and 'in extreme poverty' classifications, which are necessary for the composition of the FDI, as each corresponds to an indicator, the monthly income of each member of the family was investigated. Government aid, cash transfers, alimony and others were included, in addition to the income from paid activities. The majority of the families' members had no income $(48.6 \%)$, including the children and elderly who did not receive social benefits.

The study identified 27 families (8.4\%) below the line of extreme poverty (per capita family income of less than $1 / 4$ of a minimum salary)*, 71 (22.2\%) below

* Currently R\$622 (2012). Translator's note. 
the poverty line (per capita family income below $1 / 2$ of a minimum salary). The remaining 222 families (69.4\%) were above the poverty line (per capita family income over $1 / 2$ of a minimum salary).

The results indicated that male heads of families predominated (174 or $54.4 \%$ ), of whom 158 (90.8\%) were married or lived maritally with the partner in a stable union. It is worth emphasizing that these were not necessarily the interviewees, but that the interviewees indicated who was the head of the family.

\section{Family Development Index}

The FDI was applied to each family interviewed. Taking the proposed cut-off points into account, of the 320 families interviewed, five (1.6\%) were in an 'very high' situation of vulnerability; $47(14.7 \%)$ were in a 'high' situation, and the remaining 268 (83.7\%) were in an 'acceptable situation'(11).
The families' general FDI results from the arithmetical average of each dimension's synthetic indicators, and shows the family group's degree of vulnerability. In the present study, the general FDI was 0.77 , that is, an 'acceptable' situation, with the lowest rate being 0.39 , the highest 0.99 and the median 0.78 ( $(\mathrm{d}=0.11)$. The median is an important piece of data as it represents a homogeneity in the averages, which is considered as acceptable by the classification established. The standard deviation was low, which indicates that there is no discrepancy between the averages, that is, the families appear in a similar way in the FDI.

The synthetic indicators (the arithmetical averages of their respective components) for each dimension were also calculated, so that it would be possible to obtain a macro view of the families' reality. It is an overview, based on the dimensions proposed by the FDI ${ }^{(11)}$, of the reality of the families interviewed. Table 1 presents each dimension's synthetic indicators.

Table 1 - Descriptive statistics for the dimensions of the Family Development Index. Area covered by Urban Center 1, São Sebastião, Brasília, Federal District, Brazil, 2011

\begin{tabular}{|c|c|c|c|c|c|}
\hline Dimensions & Rate & Minimum & Maximum & Median & Standard deviation \\
\hline Absence of vulnerability & 0.78 & 0.44 & 1.00 & 0.78 & 0.12 \\
\hline Access to knowledge & 0.60 & 0.00 & 1.00 & 0.75 & 0.20 \\
\hline Access to work & 0.64 & 0.00 & 1.00 & 0.67 & 0.22 \\
\hline Availability of resources & 0.79 & 0.00 & 1.00 & 1.00 & 0.30 \\
\hline Child development & 0.94 & 0.67 & 1.00 & 1.00 & 0.08 \\
\hline Housing conditions & 0.86 & 0.38 & 1.0 & 0.88 & 0.13 \\
\hline
\end{tabular}

Of the six dimensions proposed by the FDI, none attained the 'very high' degree of vulnerability, although two stood out as 'high' situations, as they obtained a rate below 0.67: access to knowledge and access to work, with rates of 0.60 and 0.64 , respectively.

Child development was the dimension which presented the highest rate. It may be observed that the standard deviation was also low, which demonstrates homogeneity among the families in this aspect.

Even with the general FDI indicating an acceptable degree of vulnerability, five families presented a 'very high' situation of vulnerability in three of the six dimensions: access to knowledge, access to work, and availability of resources, with 'high' vulnerability in the dimension absence of vulnerability. Another 47 families presented 'very high' vulnerability in the three dimensions access to knowledge, access to work and availability of resources. The 268 families classified as in an 'acceptable situation' of vulnerability presented 'high' vulnerability in the dimension access to knowledge.

In the dimensions child development and housing conditions, the vulnerability was considered 'acceptable' for the 320 families. Table 2 shows the summary of this information.

Table 2 - Synthetic indicator of the families in the dimensions of the FDI, according to the degree of vulnerability. Area covered by Urban Center 1, São Sebastião, Brasília, Federal District, Brazil, 2011

\begin{tabular}{lccc}
\hline \multirow{2}{*}{ Dimensions } & \multicolumn{3}{c}{ Families } \\
\cline { 2 - 4 } & Very high vulnerability $(\mathbf{n = 5 )}$ & High vulnerability $(\mathbf{n = 4 7 )}$ & Acceptable vulnerability $(\mathbf{n = 2 6 8 )}$ \\
\hline Absence of vulnerability & 0.61 & 0.71 & 0.79 \\
Access to knowledge & 0.33 & 0.43 & 0.64
\end{tabular}


Table 2 - (continuation)

\begin{tabular}{lccc}
\hline \multicolumn{1}{c}{ Dimensions } & \multicolumn{2}{c}{ Families } \\
\cline { 2 - 4 } & Very high vulnerability $(\mathbf{n}=\mathbf{5})$ & High vulnerability $(\mathbf{n = 4 7 )}$ & Acceptable vulnerability $(\mathbf{n = 2 6 8 )}$ \\
\hline Access to work & 0.17 & 0.39 & 0.70 \\
Availability of resources & 0.00 & 0.37 & 0.88 \\
Child development & 0.86 & 0.91 & 0.95 \\
Housing conditions & 0.76 & 0.79 & 0.87 \\
\hline
\end{tabular}

\section{Characterization of families in very serious situations of vulnerability}

Five families were identified in a very serious situation of vulnerability, with a total of 20 persons. The members of these families were predominantly young, with an average age of 29 (standard-deviation $=22.8$ years) and a median age of 17 years. There was also a predominance of women $(60.0 \%)$, of mixed race individuals $(75.0 \%)$ and of people whose marital status was 'single' (75.0\%).

The majority had been born in the Center-West (45.0\%) and had little schooling - 60\% had not finished primary level education, and none had finished high school. Thirteen persons (65\%) had no income, including the children. The seven remaining persons (35\%) received less than a minimum salary, characterizing these families' situation of extreme poverty.

The families in a 'very high' situation of vulnerability also presented a 'very high' rate, that is, below 0.50 , in the dimensions availability of resources, access to work and access to knowledge, with rates of $(0.0),(0.17)$ and (0.33), respectively. In addition, they presented 'high' vulnerability in the dimension of absence of vulnerability, with a rate of 0.61 , as the rate is between 0.50 and 0.67 . The dimensions which presented 'acceptable' situations were child development and housing conditions, with rates of 0.86 and 0.76 , respectively.

\section{Characterization of families in a 'serious' situation of vulnerability}

The study identified 47 families in a 'high' situation of vulnerability, with a total of 217 persons. In these families too there was a predominance of women $(54.4 \%)$ and young people. The age varied from four months to 80 years, with an average of 24 years (standard deviation of 18.4 years) and a median age of 17 years.

The predominant marital situation was single (71.0\%). A low level of schooling was also identified, as $48.8 \%$ of the family members had not finished primary education, although there were more individuals who had finished high school (5.5\%) than in the families in a 'very high' situation of vulnerability, although there was not even one individual who had completed higher education.

The majority of the people had been born in the Center-West region (55.8\%), and either had no income $(61.8 \%)$, or received between one and two minimum salaries $(13.8 \%)$. Only one person $(5.0 \%)$ received between two and three minimum salaries.

In relation to the dimensions of the FDI, the families classified as in 'high' vulnerability presented a 'very high' situation of vulnerability in the dimensions availability of resources, access to work and access to knowledge, with rates of $(0.37),(0.39)$ and $(0.43)$, respectively. On the other hand, these families presented an 'acceptable' situation in the dimensions of absence of vulnerability, child development and housing conditions, with rates of $(0.71),(0.91)$ and $(0.79)$, respectively.

\section{Discussion}

In a general way, the families interviewed presented an 'acceptable' situation of vulnerability, in terms of the cut-off points established in this study for the classification of degrees of vulnerability. However, two dimensions of the FDI stand out in those in situations of 'high' vulnerability: access to knowledge and access to work.

The dimension of access to knowledge is related to the presence of illiteracy in the family and the family members' level of education. The dimension access to work considers that having access to means is as important as having the opportunity to use them to satisfy needs. It refers to the opportunity which people have to use their productive capacity in society ${ }^{(11)}$.

The dimensions showed in the 'high' situation of vulnerability gather information relating to illiteracy and the level of schooling in the family, as well as to the availability and quality of employment and the corresponding remuneration(11). This study's authors' attention was drawn to the consolidation of public policies aimed at access to knowledge and to work, conditions also observed in other studies(12). 
In relation to the dimension access to knowledge, the 2010 Census $^{(13)}$ indicates that there is inequality between the poor and the richer in the net enrolment rates, when comparing quintiles of monthly family income, which refer to total family income divided by the number of family members ${ }^{(13)}$. Access to knowledge is a dimension of the FDI which relates low schooling to the situation of vulnerability of the families interviewed.

For example, according to the 2010 Census, in the first quintile (the poorest $20 \%$ ), $32 \%$ of young people between 15 and 17 years of age were in high school, while in the last, (the richest $20 \%$ ), this proportion rose to $78 \%$ of the young, which reinforces the importance of family income in the educational context ${ }^{(13)}$.

In addition to relating education to income, the 2010 Census $^{(13)}$ indicated a growth in the access to education. According to the National Household Sample Survey (PNAD), between 1999 and 2009 there in the rate of schooling of children aged between zero and five years of age increase of $23.3 \%$ to $38.1 \%$. In the same way, practically all the children from six to fourteen years of age have been attending school since 1990, while there has also been an increase in the approval rates of children who go to school: $14.8 \%$ for children from zero to five years of age, and $6.7 \%$ for children from 15 to $17^{(13)}$.

With the increase observed in access to education, it was to be expected that the FDI, in the dimension of access to knowledge, would be in an 'acceptable' situation, as where there is increased access to school, one may anticipate improvements in family members' educational conditions. However, this situation was not identified as much in the present study as it has been in other studies addressing the same subject(11-12). This dimension presented a result indicating a situation of 'high' vulnerability, which indicates the need for improving the quality of education.

The study by the Institute of Applied Economic Research (IPEA) shows that income does not directly alter the school attendance of those in primary education, but that it is related to permanency, performance and progression in school. The poorer present higher truancy/drop-out rates and higher grade repetition rates than the richer. In this way, this condition reinforces that, in addition to ensuring access, it is necessary to invest heavily in the quality of education, as education brings opportunities for eradicating poverty and reducing social inequalities and is, therefore, related to Brazil's development ${ }^{(14)}$, as education is one of the ways to reduce families' vulnerability.
In relation to the dimension of access to work, the lack of regular and reliable income worsens families' situation of vulnerability. Precarious insertion in employment leads to exclusion from the social benefits, in comparison with workers inserted into the formal labor market ${ }^{(15)}$. These conditions are associated with the families' situations of vulnerability, as regular and reliable income guarantees the family a means of satisfying their needs, and the relationship with work is one way for a person to be able to use their productive capacity ${ }^{(11)}$.

The dimensions which were well-evaluated - that is, which presented 'acceptable' vulnerability, with FDI over 0.67, were: child development, followed by housing conditions, availability of resources and absence of vulnerability.

The dimension child development, as it presented the best performance, indicates that the children are inserted in the school context, that they are not undertaking paid activities, and that infant mortality is low, a situation also observed in another study(12). This dimension may have performed well due to primary education being guaranteed by law, which requires the State to guarantee children and adolescents' access to schooling, and because some families receive government aid which, in return, requires that children attend school and do not undertake paid work ${ }^{(14)}$.

Despite the dimension housing conditions having performed well in the FDI, the 2010 Census determined that basic sanitation services, such as treated water in the general network, a general sewerage network and daily collection of garbage (basic conditions for decent housing) are present in $62.6 \%$ of urban residences in Brazil, indicating that it is still necessary to offer these services to the rest of society ${ }^{(13)}$.

The availability of resources was also one of the dimensions which attained an acceptable FDI. This means that in a general way, the families who were interviewed were above the poverty line and that most of their resources did not come from government aid.

The dimension absence of vulnerability, related to the presence of children, the elderly and spouses, was classified as 'acceptable situation' in the families' general FDI. However, the presence of children and the absence of a spouse contributed to the rate not being high.

The analysis of the FDI made it possible to observe that the dimensions access to knowledge and access to work are correlated. If the pay or income from working is low, the opportunities for access to education are reduced. In the same way, if there is poor schooling, the opportunity to access good jobs is also compromised. 
In addition to this, it was possible to observe the need for attention and intervention responses in the areas related to education, work and income, principally for families in situations of 'serious' and 'very serious' vulnerability, which requires intersectorial and multidisciplinary actions for the response interventions.

\section{Final considerations}

The study allowed the characterization of the families in situations of 'high' and 'very high' vulnerability which, in their turn, presented needs in the areas of education, work and income. These conditions were associated with the situation of poverty, social inequalities and with the cycle of low schooling, few or no qualifications for working, and pay which is below the poverty line, which reinforces the importance of social protection for these families.

The importance is clear of using a broad concept of vulnerability in the health services, which is linked with the complex of aspects related to the collective and contextual planes of the families which need social responses, as these are more susceptible to the processes of illness, so as to acquire a differentiated outlook on these families' needs and to produce more effective responses to their health needs.

It is hoped that this study constitutes a contribution to Nursing, particularly in the area of Collective Health, as it presents a strategy for recognizing vulnerable families, along with their needs, aiming to provide guidelines for actions which fully respond to these families' needs.

\section{References}

1. Chiesa AM. A promoção da saúde como eixo estruturante da atenção à criança no Programa Saúde da Família. In: Chiesa AM, Fracolli LA, Zoboli ELCP. Promoção da Saúde da Criança. São Paulo; 2009. p. 29-42.

2. Ermel RC, Fracolli LA. O trabalho das enfermeiras no Programa de Saúde da Família em Marília/SP. Rev Esc Enferm USP. 2006;40(4):533-9.

3. Muñoz-Sánches AI, Bertolozzi MR. Pode o conceito de vulnerabilidade apoiar a construção do conhecimento científico em Saúde Coletiva? Ciênc Saúde Coletiva. 2007;12(2):319-24.

4. Nakamura E, Egry EY, Campos CMS, Nichiata LYI, Chiesa AM, Takahashi RF. O potencial de um instrumento para o reconhecimento de vulnerabilidades sociais e necessidades de saúde: saberes e práticas em saúde coletiva. Rev. Latino-Am. Enfermagem. março-abril 2009;17(2):253-8.
5. Nichiata LYI, Bertolozzi MR, Takahashi RF, Fracolli LA. A utilização do conceito "vulnerabilidade" pela enfermagem. Rev. Latino-Am. Enfermagem. set-out 2008;16(5):923-8.

6. Ayres JRCM, França I Jr, Calazans GJ, Salleti HC. Vulnerabilidade e prevenção em tempos de Aids. In: Barbosa R, Parker R, organizadores. Sexualidade pelo avesso: direitos, identidade e poder. Rio de Janeiro (RJ): Relume Dumará; 1999. p. 51.

7. Ayres JRCM, Calazans GJ, Saletti HC Filho, França I Jr. Risco, vulnerabilidade e práticas de prevenção e promoção da saúde. In: Campos et al, organizadores. Tratado de Saúde Coletiva. 2 ed. São Paulo (SP): Hucitec: Rio de Janeiro (RJ): Fiocruz; 2008. p. 375-417. 8. Instituto Brasileiro de Geografia e Estatística (IBGE). Coordenação de trabalho e rendimento. Pesquisa Nacional por Amostra de Domicílios: síntese de indicadores 2008. Rio de Janeiro; 2009.

9. Egry EY, Fonseca RMGS. A família, a visita domiciliária e a enfermagem: revisitando o processo de trabalho da enfermagem em saúde coletiva. Rev Esc Enferm USP. set $2000 ; 34(3): 233-9$.

10. Levine DM, Bereson ML, Stephan D. Estatística: Teoria e Aplicações usando Microsoft Excel em Português. Rio de Janeiro (RJ): LTC; 2000.

11. Carvalho $M$, Barros RP, Franco $S$. Índice de desenvolvimento da família. In: Acosta AR, Vitale MAF, organizadores. Família: redes e, laços e políticas. São Paulo (SP): Instituto de Estudos Especiais/Pontifícia Universidade Católica de São Paulo; 2007. p. 241-65.

12. Najar AL, Baptista TWF, Andrade CLT. Índice de desenvolvimento da família: uma análise comparativa em 21 municípios do estado do Rio de Janeiro. Brasil (BRA): Cad Saúde Pública. 2008;24(1):134-47.

13. Instituto Brasileiro de Geografia e Estatística (IBGE). Estudos e pesquisas. Informação demográfica e socioeconômica. Número 27. Síntese de indicadores sociais. Uma análise das condições de vida da população brasileira. Rio de Janeiro; 2010.

14. Instituto de Pesquisa Econômica Aplicada (IPEA). Brasil: o estado de uma nação - Estado, crescimento e desenvolvimento: a eficiência do setor público no Brasil, 2007. Brasília: IPEA; 2008.

15. Ferreira MP, Dini NP, Ferreira SP. Espaços e dimensões da pobreza nos municípios do estado de São Paulo: Índice Paulista de Vulnerabilidade Social - IPVS. São Paulo em Perspect. jan-mar 2006;20(1):5-17. 